\title{
Record of the occurrence of Lachesis muta (Serpentes, Viperidae) in an Atlantic Forest fragment in Paraíba, Brazil, with comments on the species' preservation status
}

\author{
Ricardo Rodrigues ${ }^{1 *}$ \\ Ralph Lacerda de Albuquerque ${ }^{1}$ \\ Diego José Santana ${ }^{1}$ \\ Daniel Orsi Laranjeiras ${ }^{1}$ \\ Arielson Santos Protázio ${ }^{1}$ \\ Frederico Gustavo Rodrigues França ${ }^{2}$ \\ Daniel Oliveira Mesquita ${ }^{1}$ \\ ${ }^{1}$ Universidade Federal da Paraíba, Centro de Ciências Exatas e da Natureza \\ Departamento de Sistemática e Ecologia, Laboratório de Herpetologia, Cidade Universitária \\ CEP 58059-900, João Pessoa - PB, Brazil \\ ${ }^{2}$ Universidade Federal da Paraíba, Centro de Ciências Aplicadas e Educação, Campus IV, Litoral Norte \\ Rua da Mangueira, s/n, CEP 58297-000, Rio Tinto - PB, Brazil \\ *Corresponding author \\ ricardodasilveira@gmail.com
}

Submetido em 16/07/2012

Aceito para publicação em 19/01/2013

\section{Resumo}

Registro de ocorrência de Lachesis muta (Serpentes, Viperidae) em um fragmento de Mata Atlântica na Paraíba, Brasil, com comentários sobre o status de preservação da espécie. Neste estudo é descrito um novo registro da serpente pico-de-jaca, Lachesis muta, em um fragmento de Mata Atlântica no estado da Paraíba, Nordeste do Brasil. Essa espécie é considerada a maior das serpentes peçonhentas do Novo Mundo. O espécime foi encontrado durante a noite, cruzando um atalho estreito, próximo a um declive, a aproximadamente $20 \mathrm{~m}$ de uma queda d'água. A ocorrência de L. muta nesse fragmento demonstra a importância da conservação dos fragmentos de Mata Atlântica para a preservação dessa espécie.

Palavras-chave: Conservação; Lachesis muta; Mata Atlântica; Surucucu-pico-de-jaca; Viperidae

\section{Abstract}

In this study, one describes a new record of the bushmaster snake, Lachesis muta, in an Atlantic Forest fragment in the state of Paraíba, northeastern Brazil. This species is regarded as the largest venomous snake from the New World. The specimen was found at night, crossing a narrow shortcut, close to a slope, about $20 \mathrm{~m}$ away from a waterfall. The occurrence of $L$. muta in this fragment demonstrates the importance of conservating Atlantic Forest fragments for preservating this species.

Key words: Atlantic Forest; Bushmaster; Conservation; Lachesis muta; Viperidae 
The bushmaster, Lachesis muta (Linnaeus, 1766), is the largest venomous snake species from the New World, and it is the longest viperid in the world. This species is widely distributed in tropical forests of Brazil, the Guyanas, Venezuela, Trinidad, Bolivia, Peru, Ecuador, and Colombia (CAMPBELL; LAMAR, 2004).

Until 2004, L. muta was recognized as a polytypic species, consisting of two subspecies: L. muta muta (Linnaeus, 1766), occurring in the Amazon Forest, and $L$. muta rhombeata (Wied-Neuwied, 1824), occurring in the Brazilian Atlantic Forest (ZAMUDIO; GREENE, 1997; CAMPBELL; LAMAR, 2004). According to the Livro vermelho da fauna brasileira ameaçada de extinção (IUCN redlist), L. m. rhombeata is regarded as being from vulnerable (VU) to critically endangered (CE) (MARTINS; MOLINA, 2008). In a systematic review on the genus, Fernandes et al. (2004) regarded both names as being synonyms of L. muta, something which, as a consequence, excludes the species from the IUCN redlist (IUCN, 2012). However, the population identified in the Atlantic Forest is still regarded as endangered due to nearly complete habitat destruction (over 90\%) in order to create agricultural areas (WARREL et al., 2010).
This paper reports a new record of Lachesis muta in the Atlantic Forest, in the town of Cruz do Espírito Santo, Paraíba, Brazil (07¹0'48.8"S, 35 05'39.0"W; Figure 1). This area is a legal reserve of Usina de São João, called "Mata do Açude Cafundó", within a monoculture sugarcane matrix. The habitat, around 730ha in size, is a seasonal semideciduous forest area, with a tropical equatorial climate. It is characterized by a mix of secondary-growth Atlantic Forest vegetation, with isolated open Cerrado areas, called "tabuleiros". The L. muta specimen (Figure 2) was observed on November 6, 2010, at night (9:15 p.m.). The animal was observed crossing a shortcut, on a slope, about $20 \mathrm{~m}$ away from a waterfall. The specimen was an adult male, $1.99 \mathrm{~m}$ long. The specimen presented an aggressive defensive behavior, striking on the collector's direction $(1.5 \mathrm{~m}$ away and $1.5 \mathrm{~m}$ in height), when touched with a snake hook. After this initial aggressive response, the specimen remained coiled on the ground until it was collected. The specimen was incorporated into the Herpetological Collection of Universidade Federal da Paraíba, under the label CHUFPB 00001 (collection permit 15363-1 IBAMA/SISBIO).

FIGURE 1: Lachesis muta in Cruz do Espírito Santo, Paraíba, Brazil (CHUFPB 00001).

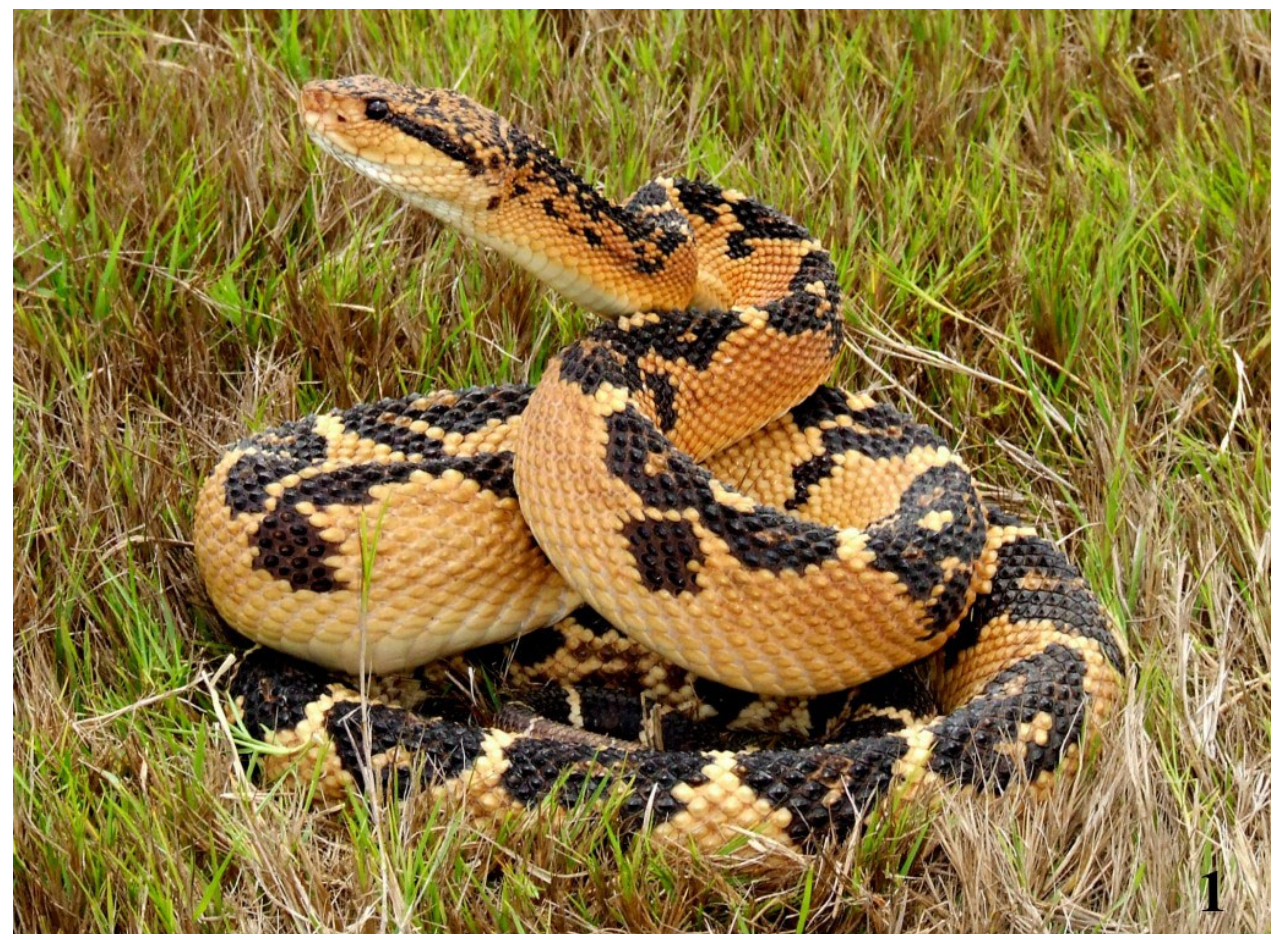

Source: Photograph taken by Diego José Santana. 
FIGURE 2: Distribution of Lachesis muta in northeastern Brazil*.

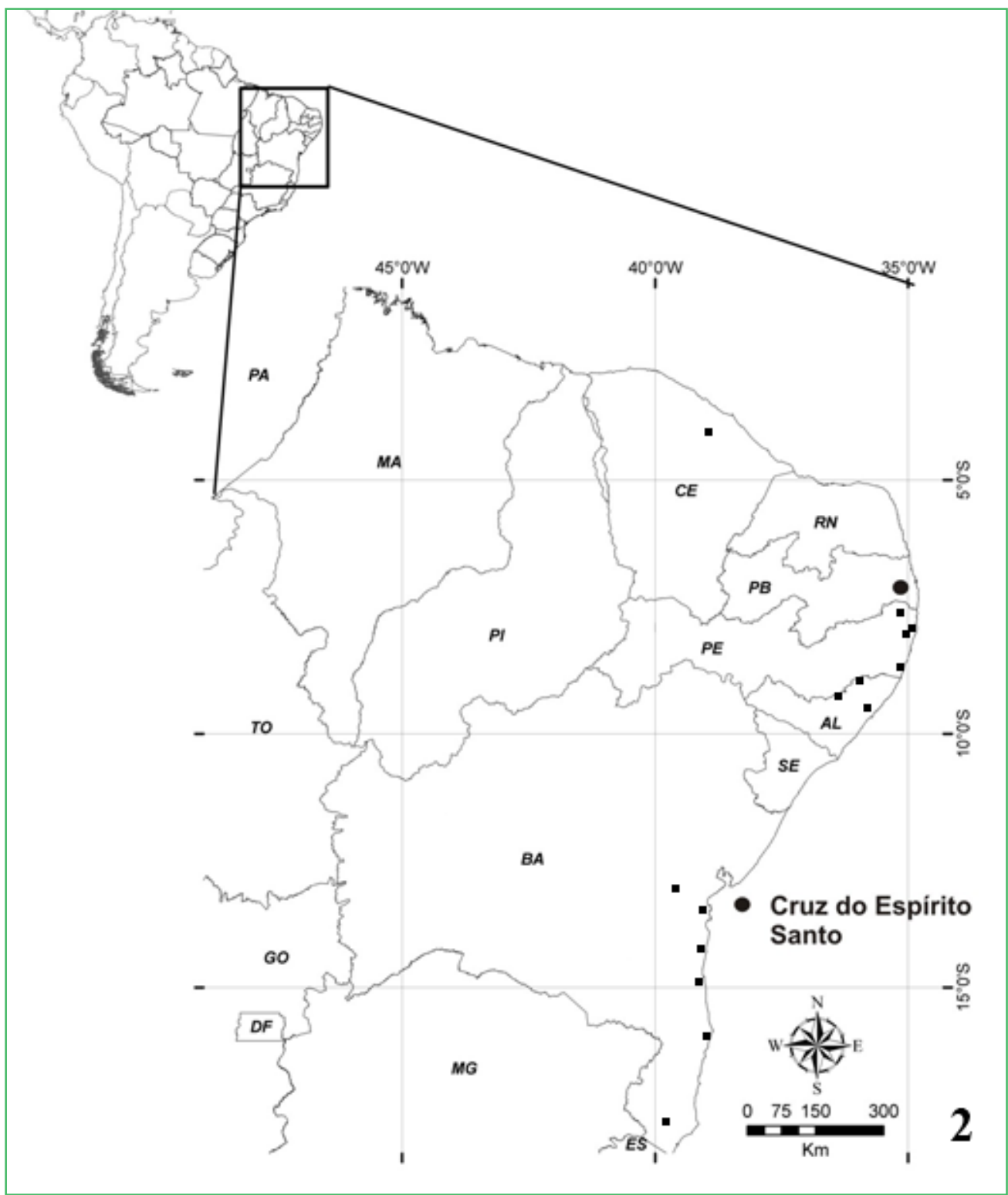

*Circle: new record; squares: records in the literature (CAMPBELL; LAMAR, 2004; FERNANDES et al., 2004).

Accidents involving venomous snakes constitute a public health problem in Brazil. The severity of these cases could be minimized through useful information with regard to snake accidents (LEMOS et al., 2009). Nevertheless, Argôlo (2003) presented another perspective on the aggressiveness of bushmasters, reporting that out of the 26 cases observed, only 3 specimens showed an aggressive defensive behavior, i.e. striking towards the collector. In the state of Paraíba, there is evidence of two cases of envenomation by
Lachesis bites, both of them occurred in 1994 and non-lethal. These specimens were $1.78 \mathrm{~m}$ and $1.85 \mathrm{~m}$ long, male and female, respectively, and they were incorporated into the collection of the Toxicological Assistance Center (CEATOX, UFPB) (CARVALHOJÚNIOR et al., 1994).

The Atlantic Forest is one of the most important biodiversity hotspots in the world (MITTERMEIER et al., 2005). In Brazil, this biome and its associated ecosystems have about 100,000 ha nowadays - only 
$7-8 \%$ of the original area still remains (MMA, 2000). Lira-da-Silva et al. (2009) carried out a survey in 17 Brazilian scientific collections and they recorded only 101 L. muta specimens from northeastern Brazil. Out of these, $93 \%$ were collected in the state of Bahia. This survey reveals the rarity of bushmaster populations in northeastern Brazil, presumably because this species is restricted to forest fragments (CAMPBELL; LAMMAR, 2004), which are very scarce nowadays (MMA, 2000). Decrease in the remaining Atlantic Forest fragments, combined with increase in its discontinuity, and, as a consequence, geographical population isolation, is the main cause of biodiversity reduction in these areas, something which could also reduce the survival rate of future generations (PÔRTO et al., 2006). The occurrence of L. muta in the forest fragment in Cruz do Espírito Santo provides positive evidence with regard to the importance of these remaining Atlantic Forest fragments.

\section{Acknowledgements}

The authors thank the Brazilian Institute of Environment and Renewable Natural Resources (IBAMA). DJS would like to thank CAPES for his current PhD scholarship, REUNI for the scholarships to ASP and RR, and CNPq for the research fellowship to DOM. FGRF thanks the financial support from CNPq (Universal Grant 474250/2010-5). DOM thanks the financial support from $\mathrm{CNPq}$ (Universal Grant 481537/2009-0). The authors also thank Sara Ruane and Tim Colston for their observations and suggestions.

\section{References}

ARGÔLO, A. J. S. Lachesis muta rhombeata Wied, 1825 (Serpentes, Viperidae): Defensive Behavior and Snakebite Risk. Herpetological Review, St. Louis, v. 34, n. 3, p. 210-211, 2003.

CAMPBELL, J. A.; LAMAR; W. W. 2004. Venomous reptiles of the western hemisphere. v. 2. Ithaca: Comstock Publishing Associates, 2004. 962 p.
CARVALHO-JÚNIOR, A. M.; ALENCAR, V. P.; COSTA, F. G.; CABRAL, B.; DIAS, E. P. F.; ARRUDA-JÚNIOR, E. R. Acidentes ofídicos por Surucucu (Lachesis muta rhombeata). Relato de dois casos atendidos no HU. Ciência, Cultura, Saúde, João Pessoa, v. 8, n. 3, p. 11-14, 1994.

FERNANDES, D. S.; FRANCO, F. L.; FERNANDES, R. Systematic revision of the genus Lachesis Daudin, 1803 (Serpentes, Viperidae). Herpetologica, Lawrence, v. 60, n. 2, p. 245-260, 2004.

IUCN. IUCN red list of threatened species. Version 2012.2. Available in: <www.iucnredlist.org $>$. Downloaded on: 18 January 2013.

LEMOS, J. C.; ALMEIDA, T. D.; FOOK, S. M. L.; PAIVA, A. A.; SIMÕES, M. O. S. Epidemiologia dos acidentes ofídicos notificados pelo Centro de Assistência e Informação Toxicológica de Campina Grande (CEATOX - CG), Paraíba. Revista Brasileira de Epidemiologia, São Paulo, v. 12, n. 1, p. 50-59, 2009.

LIRA-DA-SILVA, R. M.; MISE, Y. F.; CASAIS-E-SILVA, L. L.; ULLOA, J.; HAMDAN, B.; BRAZIL, T. K. Serpentes de importância médica do Nordeste do Brasil. Gazeta Médica da Bahia, Salvador, v. 79, n. 1, p. 7-20, 2009.

MARTINS, M.; MOLINA, F. B. Panorama geral dos répteis ameaçados do Brasil. In: MACHADO, A. B. M.; DRUMMOND, G. M. A.; PAGLIA, P. (Ed.). Livro vermelho da fauna brasileira ameaçada de extinção. v. 2. Brasília e Belo Horizonte: MMA e Fundação Biodiversitas, 2008. p. 327-334.

MITTERMEIER, R. A.; GIL, P. R.; HOFFMAN, M.; PILGRIM, J.; BROOKS, T.; MITTERMEIER, C. G.; LAMOREUX, J.; FONSECA, G. A. B. Hotspots revisited: earth's biologically richest and most endangered terrestrial ecoregions. Mexico City: CEMEX and Agrupación Sierra Madre, 2005. 392 p.

MINISTÉRIO DO MEIO AMBIENTE - MMA. Avaliação e ações prioritárias para a conservação da biodiversidade da Mata Atlântica e Campos Sulinos. Brasília: Conservation International do Brasil, Fundação SOS Mata Atlântica, Fundação Biodiversitas, 2000. 40 p.

PÔRTO, K. C.; ALMEIDA-CORTEZ, J. S.; TABARELLI, M. Diversidade biológica e conservação da Floresta Atlântica ao Norte do Rio São Francisco. Brasília: MMA, Biodiversidade 14, 2006. 363 p.

WARREL, D. A.; THEAKSTON, R. D. G.; WÜSTER, W. Destruction of the collection of reptiles and arthropods at Butantan Institute: a view from the United Kingdom. The Journal of Venomous Animals and Toxins including Tropical Diseases, Botucatu, v. 16, n. 4, p. 534-536, 2010.

ZAMUDIO, K. R.; GREENE, H. W. Phylogeography of the Bushmaster (Lachesis muta: Viperidae): implications for neotropical biogeography, systematics, and conservation. Biological Journal of the Linnean Society, London, v. 62, p. 421-442, 1997. 